\title{
Reseña. Carlos Aguasaco. The New York City Subway Poems/Poemas del metro de Nueva York. Ashland Poetry Press, 2020
}

\section{Review. Carlos Aguasaco. The New York City Subway Poems/Poemas del metro de Nueva York. Ashland Poetry Press, 2020}

Con el peso del bagaje de seis poemarios publicados, uno de ellos traducido al árabe, otro al francés, una novela corta, once antologías literarias editadas, y un exhaustivo estudio académico sobre el personaje de "El chapulín colorado" nos llega, en edición bilingüe, el más reciente poemario de Carlos Aguasaco, poeta y académico colombiano: Poemas del metro de Nueva York/ The New York City Subway Poems, en traducción de Carol O’Flynn y Pilar González.

La colección está dividida en seis secciones de variada extensión: I. Poemas del metro de Nueva York: 21 poemas, II. Diente de plomo: 14, III. En el bastidor del mundo: solo un poema dividido en cinco partes, IV. Mil noches y una noche: solo un poema el cual lleva el mismo título, V. Cara y cruz: 12, y VI. Nocturnos del caminante: 20 .

Adentrarse en Poemas del metro de Nueva York es tomar las maletas y partir en un viaje balanceándonos sobre el doble filo del sentimiento y la razón; viaje 
CATEDRAL TOMADA: Revista de crítica literaria latinoamericana / Journal of Latin American Literary Criticism

Reseña. Carlos Aguasaco. The New York City Subway Poems/Poemas del metro de Nueva York. Ashland Poetry Press, 2020

introspectivo por la emoción provocada por las persistentes imágenes de violencia, soledad, nostalgia, muerte, por un lado, y por el otro, por la búsqueda de los porqués.

En los 21 poemas de la primera sección: "Poemas del metro", recorremos el ambiente que rodea al habitante de Nueva York, sobre todo al inmigrante; sus sentimientos, sus penas, sus dificultades, sus escasas alegrías. Somos partícipes del desprecio, la falta de acogida prodigada desde arriba, a este grupo de nuevos llegados. Clama en grito desgarrador el emigrante pobre, el emigrante negro, moreno, amarillo venido de latitudes no bienvenidas: "Nueva York, no es a mí a quien saludas/con tu antorcha encendida en el Atlántico" ("Nueva York" 14), antorcha enarbolada por "una dama francesa que le sonríe a Europa" ("Del buen sentido" 26).

Es en esa ciudad vertiginosa de contrastes cielo-tierra, desplazándonos en su metro, arteria de agitación, transformación y muerte donde nos asomamos a la vida que nos espera cuando no somos europeos, y porque "jamás perderemos el acento" (26); donde aprendemos el nuevo lenguaje, no de la vida sino del trabajo a morir, "la lengua de los brazos" (“Oración 30), para lo cual es preciso "olvidar que existe el tiempo libre" (30), donde la regla es tratar de borrarse para sobrevivir en esta jungla que es Nueva York.

Para el emigrante, Nueva York está también habitado por presencias y ausencias, amores y desamores; por la tristeza del que ha llegado a sus orillas, y su nostalgia por el, la y lo que dejó atrás. Por la suerte de tener un trabajo, alquilar un departamento con "una ventana de dos pies cuadrados" ("Suerte" 36), por la soledad dentro de la muchedumbre y el silencio entre el ruido que la golpea:

Los viajeros pasan y lo ignoran en su afán, los mendigos pasan y lo esquivan con su propia angustia, los turistas pasan y se toman fotos sin notar su presencia, los soldados pasan[...] 
todos siguen su camino,

$$
\text { nadie calla[...]. }
$$

Pero esta ciudad nos permite también afirmarnos en el poder de nuestra capacidad creadora, en la posibilidad de desplazar nuestro yo creador fraterno, solidario, y ponerlo al servicio de quien necesite su voz para hacerse escuchar en ese viaje incesante del metro que día a día, en intervalos de 5 a 7 minutos, da vida a Nueva York:

en el metro, las gentes me miran como pidiendo auxilio

$[\ldots]$

Una palabra tuya bastará para que salte de la silla

e inicie una recitación en mi lengua materna.

$[\ldots]$

¡Préstame tu nombre, Carlos Aguasaco,

déjame ser esa voz que te dicta el poema!

La sección "Diente de plomo" nos saca de la urbe neoyorquina para llevarnos a Latinoamérica y su universo de narcoviolencia y feminicidio personificado en Juárez, un lugar donde hasta la muerte llora: "No lo vas a creer, pero te digo que la encontré llorando" (80), un universo donde la tradición se moderniza y los jóvenes, asiduos del internet, mantienen viva la memoria de sus muertos en el muro sin lápidas de Facebook ("Todos los días se pierden amigos" 82).

A través de los catorce poemas de esta sección el poeta nos enfrenta a un frío y punzante retrato de la muerte, pan de cada día en Juárez, y una sensación de espanto nos recorre el cuerpo y nos remece al pensar que acostumbrarse a esperar la muerte a la vuelta de cualquier esquina como lo más normal de la vida es el terrible sentimiento de cada persona cada día al despertarse no solo en Juárez, sino también en Bogotá, o en cualquier lugar donde la muerte viciada tiene el as de la 
CATEDRAL TomAdA: Revista de crítica literaria latinoamericana / Journal of Latin American Literary Criticism

Reseña. Carlos Aguasaco. The New York City Subway Poems/Poemas del metro de Nueva York. Ashland Poetry Press, 2020

baraja: "Morir así entre el fuego cruzado del Narco y los Federales, morir así de gratis sin llegar a tu casa con el pan de la mañana[...]" (62).

El marasmo en que puede sumirnos la aceptación involuntaria de la cotidianidad de la muerte causada por la narcoviolencia es atacada por Aguasaco en el poema "Escoge bien tus armas", pues hay armas que matan, como las de la narcoviolencia, y otras que dan vida: las del poeta. En el poema, el poeta nos confronta a nuestra parte de responsabilidad en la historia al interpelarnos con el imperativo "escoge bien tus armas", pues en este juego a la ruleta "no se aceptan cambios" (78) y como individuo debemos tener el temple y la valentía de pesar las consecuencias de nuestra elección más allá de lo individual.

Una muestra magistral del poder del verso presente en la apuesta de Aguasaco por las armas del poeta se encuentra en su poema "Las muertas de Juárez" donde en crescendo, en un juego sublime y a la vez macabro que va desde Adriana hasta Zulema nos llama a ponerles caras a las mujeres asesinadas en Juárez, a crearles una vida, a convertirlas en nuestras hermanas, madres, parejas, para obligarnos a salir del sopor de la indiferencia y reaccionar: "¿[...]o de la mujer sin nombre que ha muerto más de setenta veces, de la mujer sin nombre que - ¡ay! ¡ay! ¡ay! ¡ay! ¡ay! ¡ay! ¡Dios mío! - sigue muriendo en Juárez sin que nadie haga ni diga nada?" (70).

La sección termina con un esclarecimiento y llamado a la reflexión y a no caer en la tentación de la llamada narcopoética. Si bien es cierto la violencia del narcotráfico ha dado tema de creación artística, conlleva el peligro de anclarnos en la costumbre que paraliza, "a convivir con la muerte como si fuera nuestra vecina o compañera de trabajo" (90), a comprimir el espacio y el tiempo, a borrar los límites de la razón, la moral, la decencia.

La muerte, la nostalgia y el viaje también hacen parte de las otras cuatro secciones de la colección, pero de manera más críptica y personal: "Yo moriré en silencio con los ojos abiertos" (127). La prosa poética de Aguasaco es rica en imágenes de un lirismo fresco, a veces ligero y vital, a veces macabro y dolido: 
“¿Quién pasará de largo ocultando que me conoce?” ("Primer nocturno del caminante" 139).

Al finalizar el viaje, nuestras valijas regresan a puerto cargadas de recuerdos e inquisitivas voces que quedan rebotando en nuestra mente para siempre, reflejos innegables de una profunda certeza: la fuerza que nos aporta la poesía para poder continuar nuestro viaje por la vida sin enloquecer.

Y resuena en nuestros oídos, con acento entrecortado vallejiano, el grito de la ciudad: "Regresa Carlos Aguasaco, poeta que viaja en metro [...] déjame ser esa voz que te dicta el poema" (48).

(cc) $\mathbf{E Y} \quad$ New articles in this journal are licensed under a Creative Commons Attribution 4.0 United States License. 